\title{
Test Analysis on Gravity Strength Exercise of Swimmers
}

\author{
Ting Liao \\ Swimming teaching and research facilities., Wuhan Inst. of P.E., Wuhan 430079, \\ P.R. China \\ liaoting1982126@126.com
}

\begin{abstract}
The exercise approach to the maximum power for iron sheet pull of first-tier athletes of Hubei Provincial Swimming Team was tested with proprietary strength quality testing facility. Results indicated the possibility of assessing the strength quality of a swimmer by power changes and the strength level by the amplitude of power transformation; the simple test method could be used as a guide on the exercise of swimmers.
\end{abstract}

Keywords-swimmer; gravity strength; test analysis; power

\section{INTRODUCTION}

In their preparation for the $12^{\text {th }}$ National Games, the gravity strength exercise for swimming of Hubei Province is typically by means of iron sheet chest developers with which swimmers exercise their strength by repeatedly overcoming the resistance arising out of certain levels of weights. The key problem with this method, however, lies in the absence of a simple and applicable monitoring device for the exercise practice. Coaches only know the mass of the weights, the counts of the movements and the time needed to perform a set of exercise, but have no idea about the exact parameters crucial to them; how much force is applied to the weights, how much work is made, how does the power change, how does the frequency fluctuate, when does the athlete's strength start to deteriorate and how much is such deterioration. It is the absence of an effective testing and monitoring means that prevents coaches from assessing the accurate effect of sports exercise and consequently from improving the exercise performance. In view of this, our test was conducted to explore for the possibility of analyzing and assessing the effect of practical strength exercise on excellent swimmers with a simple and applicable exercise monitoring system.

Recently, the first "test and assessment system for gravity strength exercise" designed to measure barbell exercise in China was initially developed by the project team. Testing practice has confirmed that under a certain weight level, assessing the strength quality of an athlete with power is a very effective way. In our study, the maximum power for iron sheet pull of first-line athletes of Hubei Provincial Swimming Team was tested. Results indicated that assessing the strength level of an athlete with power is both convenient and effective.

\section{PRINCIPLE AND METHOD}

\section{A. Principle}

According to conversation of energy, any strength exercise is a process that transforms the chemical energy stored in the body into mechanical energy by changing the speed or acceleration and increasing the kinetic energy or potential energy of the weight, and into heat energy through heat exchange and heat radiation in the form of surface temperature rise and sweating. The strength of an athlete is right reflected by his or her ability to transform into mechanical energy.

The level of ability is reflected by the total amount of transformation and the efficiency of transformation. As mechanical energy can be represented by the work made by the body to overcome the resistance, the amount of exercise can be represented by the work W= FS. In the same way, the total amount of mechanical energy transformed can be measured by the total work made to overcome the resistance while the efficiency of the transformation by the power made to overcome the resistance within a unit time, i.e. the power. The average power $\mathrm{P}$ of a force application is expressed by:

$$
P=\int F \mathrm{~d} v=\frac{1}{T} \int_{0}^{T} F v \mathrm{~d} t=F v
$$

Where: $T$ total time of a force application.

As said above, for monitoring strength exercise and assessing abilities, the load mass $\mathrm{m}$, pull velocity $\mathrm{v}$, acceleration $\mathrm{a}$, force $\mathrm{F}$ and power $\mathrm{P}$ are all very critical parameters, so are the graphic features of each of these parameters.

\section{B. Testing facility}

The system consists of a sensor system, a feed rope steering system and a storage and display system. The sensor system transforms displacement and other physical values into electrical signals and enters them into the computer. The feed rope steering system keeps the entire system moving to and fro. The storage and display system is responsible for calculating and processing data. 


\section{Parameters}

1)Pull-up velocity $V$. Given that for each pull, the pull-up length is $\mathrm{L}$ and the pull-up time is $\mathrm{T}$, then the pull-up velocity can be defined as $\mathrm{V}=\mathrm{LT}$, meaning the average pull-up velocity.

2)Maximum pull-up velocity $V_{\text {upmax. }}$ As shown in Fig 1 , the velocity during each pull changes all the time: it gradually increases and then gradually decreases during which a maximum velocity is produced. That is the maximum pull-up velocity $V_{\text {upmax }}$.

3)Pull-up power $P$. Power represents the work made by an athlete within a unit time. The pull-up power $P_{u p}$ during each pull can be defined as:

$$
P_{u p}=\frac{\int_{0}^{T_{u p}}|F v| \mathrm{d} t}{T_{u p}}
$$

\section{RESULTS AND ANALYSIS}

The maximum power for iron sheet pull of 4 first-tier athletes of Hubei Provincial Swimming Team, including backstroke swimmer Zhao who had won many international and domestic competitions, was tested. Table 3-1 shows the sequence and weights of the test. Table 3-2 shows the test result.

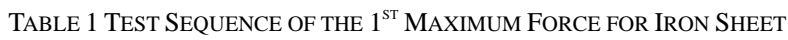
PULL

\begin{tabular}{|c|c|c|c|c|c|c|c|c|c|c|c|}
\hline \multirow{2}{*}{$\begin{array}{l}\text { S } \\
\text { e } \\
\text { q }\end{array}$} & \multirow{2}{*}{$\begin{array}{l}\mathrm{Na} \\
\text { me }\end{array}$} & \multirow{2}{*}{ Sex } & \multirow{2}{*}{ Style } & \multicolumn{2}{|c|}{ Round 1} & \multicolumn{2}{|c|}{ Round 2} & \multicolumn{2}{|c|}{ Round 3} & \multicolumn{2}{|c|}{ Round 4} \\
\hline & & & & $\begin{array}{l}\mathrm{W} \\
\mathrm{T}\end{array}$ & $\begin{array}{l}\text { Co } \\
\text { unt }\end{array}$ & $\begin{array}{l}\mathrm{W} \\
\mathrm{T}\end{array}$ & $\begin{array}{l}\text { Co } \\
\text { unt }\end{array}$ & $\begin{array}{l}\text { Co } \\
\text { unt }\end{array}$ & $\begin{array}{l}\mathrm{W} \\
\mathrm{T}\end{array}$ & $\begin{array}{l}\text { Co } \\
\text { unt }\end{array}$ & $\begin{array}{l}W \\
T\end{array}$ \\
\hline 1 & $\begin{array}{c}\text { Jin } \\
\text { g } \\
\mathrm{Zh} \\
\text { ao } \\
\end{array}$ & $\begin{array}{c}\mathrm{Fe} \\
\mathrm{mal} \\
\mathrm{e}\end{array}$ & $\begin{array}{l}\text { Backs } \\
\text { troke }\end{array}$ & $\begin{array}{l}10 \\
\mathrm{~kg}\end{array}$ & 5 & $\begin{array}{l}15 \\
\mathrm{~kg}\end{array}$ & 3 & $\begin{array}{l}20 \\
\mathrm{~kg}\end{array}$ & 3 & $\begin{array}{l}25 \\
\mathrm{~kg}\end{array}$ & 2 \\
\hline 2 & $\begin{array}{c}\mathrm{Si} \\
\mathrm{Hu} \\
\text { ang }\end{array}$ & $\begin{array}{c}\text { Mal } \\
\text { e }\end{array}$ & $\begin{array}{l}\text { Backs } \\
\text { troke }\end{array}$ & $\begin{array}{l}10 \\
\mathrm{~kg}\end{array}$ & 5 & $\begin{array}{l}15 \\
\mathrm{~kg}\end{array}$ & 3 & $\begin{array}{l}20 \\
\mathrm{~kg}\end{array}$ & 3 & $\begin{array}{l}25 \\
\mathrm{~kg}\end{array}$ & 2 \\
\hline 3 & $\begin{array}{c}\text { Ha } \\
\text { o } \\
\text { Qiu }\end{array}$ & $\begin{array}{c}\text { Mal } \\
\text { e }\end{array}$ & $\begin{array}{l}\text { Backs } \\
\text { troke }\end{array}$ & $\begin{array}{l}10 \\
\mathrm{~kg}\end{array}$ & 5 & $\begin{array}{l}15 \\
\mathrm{~kg}\end{array}$ & 3 & $\begin{array}{l}20 \\
\mathrm{~kg}\end{array}$ & 3 & $\begin{array}{l}25 \\
\mathrm{~kg}\end{array}$ & 2 \\
\hline 4 & $\begin{array}{c}\text { Lei } \\
\text { Ya } \\
\text { n }\end{array}$ & $\begin{array}{c}\mathrm{Fe} \\
\text { mal } \\
\mathrm{e}\end{array}$ & $\begin{array}{l}\text { Breast } \\
\text { roke }\end{array}$ & $\begin{array}{l}10 \\
\mathrm{~kg}\end{array}$ & 5 & $\begin{array}{l}15 \\
\mathrm{~kg}\end{array}$ & 3 & $\begin{array}{l}20 \\
\mathrm{~kg}\end{array}$ & 3 & $\begin{array}{l}25 \\
\mathrm{~kg}\end{array}$ & 2 \\
\hline \multirow{2}{*}{$\begin{array}{l}\mathrm{S} \\
\mathrm{e} \\
\mathrm{q}\end{array}$} & \multirow{2}{*}{$\begin{array}{l}\mathrm{Na} \\
\mathrm{me}\end{array}$} & \multirow[b]{2}{*}{ Sex } & \multirow{2}{*}{ Style } & \multicolumn{2}{|c|}{ Round 1} & \multicolumn{2}{|c|}{ Round 2} & \multicolumn{2}{|c|}{ Round 3} & \multicolumn{2}{|c|}{ Round 4} \\
\hline & & & & $\begin{array}{l}\mathrm{W} \\
\mathrm{T}\end{array}$ & $\begin{array}{l}\text { Co } \\
\text { unt }\end{array}$ & $\begin{array}{l}\mathrm{W} \\
\mathrm{T}\end{array}$ & $\begin{array}{l}\text { Co } \\
\text { unt }\end{array}$ & $\begin{array}{l}\text { Co } \\
\text { unt }\end{array}$ & $\begin{array}{l}\mathrm{W} \\
\mathrm{T}\end{array}$ & $\begin{array}{l}\text { Co } \\
\text { unt }\end{array}$ & $\begin{array}{l}\mathrm{W} \\
\mathrm{T}\end{array}$ \\
\hline 1 & $\begin{array}{c}\text { Jin } \\
\text { g } \\
\mathrm{Zh} \\
\text { ao } \\
\end{array}$ & $\begin{array}{c}\mathrm{Fe} \\
\mathrm{mal} \\
\mathrm{e}\end{array}$ & $\begin{array}{l}\text { Backs } \\
\text { troke }\end{array}$ & $\begin{array}{l}30 \\
\mathrm{~kg}\end{array}$ & 2 & $\begin{array}{l}35 \\
\mathrm{~kg}\end{array}$ & 1 & $\begin{array}{l}40 \\
\mathrm{~kg}\end{array}$ & 1 & $\begin{array}{l}45 \\
\mathrm{~kg}\end{array}$ & 1 \\
\hline 2 & $\begin{array}{c}\mathrm{Si} \\
\mathrm{Hu} \\
\text { ang } \\
\end{array}$ & $\begin{array}{c}\text { Mal } \\
\text { e }\end{array}$ & $\begin{array}{l}\text { Backs } \\
\text { troke }\end{array}$ & $\begin{array}{l}30 \\
\mathrm{~kg}\end{array}$ & 2 & $\begin{array}{l}35 \\
\mathrm{~kg}\end{array}$ & 1 & $\begin{array}{l}40 \\
\mathrm{~kg}\end{array}$ & 1 & 1 & 1 \\
\hline 3 & $\begin{array}{c}\text { Ha } \\
\text { o } \\
\text { Qiu }\end{array}$ & $\begin{array}{c}\text { Mal } \\
\text { e }\end{array}$ & $\begin{array}{l}\text { Backs } \\
\text { troke }\end{array}$ & $\begin{array}{l}30 \\
\mathrm{~kg}\end{array}$ & 2 & $\begin{array}{l}35 \\
\mathrm{~kg}\end{array}$ & 1 & 1 & 1 & 1 & 1 \\
\hline 4 & $\begin{array}{c}\text { Lei } \\
\text { Ya } \\
\text { n }\end{array}$ & $\begin{array}{c}\mathrm{Fe} \\
\mathrm{mal} \\
\mathrm{e}\end{array}$ & $\begin{array}{c}\text { Breast } \\
\text { roke }\end{array}$ & $\begin{array}{l}30 \\
\mathrm{~kg}\end{array}$ & 2 & $\begin{array}{l}35 \\
\mathrm{~kg}\end{array}$ & 1 & 1 & 1 & 1 & 1 \\
\hline
\end{tabular}

TABle 3-2 Test Result of the Maximum Power For Iron SheEt PULL

\begin{tabular}{|c|c|c|c|c|c|c|c|c|}
\hline $\begin{array}{l}\mathrm{N} \\
\mathrm{o}\end{array}$ & $\begin{array}{c}\mathrm{Nam} \\
\mathrm{e}\end{array}$ & $\begin{array}{l}\text { Te } \\
\text { st } \\
W \\
\mathrm{~T} \\
(\mathrm{k} \\
\mathrm{g})\end{array}$ & $\begin{array}{c}\text { Max } \\
\text { pull-ba } \\
\text { ck } \\
\text { velocit } \\
y \\
(\mathrm{~m} / \mathrm{s})\end{array}$ & $\begin{array}{c}\text { Max } \\
\text { pull-back } \\
\text { accelerati } \\
\text { on } \\
(\mathrm{m} / \mathrm{s} 2)\end{array}$ & $\begin{array}{c}\text { Ma } \\
\mathrm{x} \\
\text { pull } \\
\\
(\mathrm{kg})\end{array}$ & $\begin{array}{l}\text { Avg } \\
\text { pull-ba } \\
\text { ck } \\
\text { power } \\
\text { (w) }\end{array}$ & $\begin{array}{c}\text { Avg } \\
\text { pull-ba } \\
\text { ck } \\
\text { velocit } \\
\text { y } \\
(\mathrm{m} / \mathrm{s})\end{array}$ & $\begin{array}{l}\text { Pull/wei } \\
\text { ght ratio }\end{array}$ \\
\hline 1 & Zhao & \multirow{4}{*}{10} & 1.26 & 6.86 & $\begin{array}{c}13.3 \\
9\end{array}$ & 79.16 & 0.81 & 1.34 \\
\hline 2 & $\begin{array}{c}\text { Hua } \\
\text { ng }\end{array}$ & & 1.65 & 6.92 & $\begin{array}{c}15.4 \\
3\end{array}$ & 93.83 & 0.95 & 1.54 \\
\hline 3 & QIu & & 1.37 & 7.81 & $\begin{array}{c}14.2 \\
3\end{array}$ & 82.69 & 0.85 & 1.42 \\
\hline 4 & Yan & & 0.75 & 5.12 & $\begin{array}{c}12.0 \\
3\end{array}$ & 46.04 & 0.48 & 1.2 \\
\hline 1 & Zhao & \multirow{4}{*}{15} & 1.15 & 7.06 & $\begin{array}{c}20.1 \\
9\end{array}$ & 100.77 & 0.69 & 1.35 \\
\hline 2 & $\begin{array}{c}\text { Hua } \\
\text { ng }\end{array}$ & & 1.47 & 5.83 & $\begin{array}{c}21.4 \\
8\end{array}$ & 130.53 & 0.89 & 1.43 \\
\hline 3 & QIu & & 1.14 & 6.73 & $\begin{array}{c}19.6 \\
7\end{array}$ & 110.34 & 0.76 & 1.31 \\
\hline 4 & Yan & & 0.63 & 4.2 & $\begin{array}{c}17.3 \\
5\end{array}$ & 60.37 & 0.42 & 1.16 \\
\hline 1 & Zhao & \multirow{4}{*}{20} & 0.98 & 5.46 & 25.4 & 115.67 & 0.6 & 1.27 \\
\hline 2 & $\begin{array}{c}\text { Hua } \\
\text { ng }\end{array}$ & & 1.23 & 4.52 & $\begin{array}{c}26.2 \\
5\end{array}$ & 146.35 & 0.75 & 1.31 \\
\hline 3 & QIu & & 1 & 5.56 & $\begin{array}{c}24.7 \\
8\end{array}$ & 136.46 & 0.7 & 1.24 \\
\hline 4 & Yan & & 0.54 & 3.61 & $\begin{array}{c}22.8 \\
7\end{array}$ & 64.31 & 0.33 & 1.14 \\
\hline 1 & Zhao & \multirow{4}{*}{25} & 0.8 & 4.32 & $\begin{array}{c}29.8 \\
5\end{array}$ & 90.63 & 0.37 & 1.19 \\
\hline 2 & $\begin{array}{c}\text { Hua } \\
\text { ng }\end{array}$ & & 1.1 & 4.17 & $\begin{array}{c}31.8 \\
5\end{array}$ & 167.99 & 0.69 & 1.27 \\
\hline 3 & QIu & & 0.88 & 4.01 & $\begin{array}{c}30.2 \\
5\end{array}$ & 147.76 & 0.61 & 1.21 \\
\hline 4 & Yan & & 0.5 & 2.44 & $\begin{array}{c}28.0 \\
2\end{array}$ & 75.7 & 0.32 & 1.12 \\
\hline 1 & Zhao & \multirow{4}{*}{30} & 0.7 & 2.66 & $\begin{array}{c}34.8 \\
3\end{array}$ & 96.92 & 0.33 & 1.16 \\
\hline 2 & $\begin{array}{c}\text { Hua } \\
\text { ng }\end{array}$ & & 0.99 & 3.73 & $\begin{array}{c}37.6 \\
3\end{array}$ & 177.55 & 0.61 & 1.25 \\
\hline 3 & QIu & & 0.81 & 4.46 & $\begin{array}{c}35.3 \\
9\end{array}$ & 136.67 & 0.47 & 1.18 \\
\hline 4 & Yan & & 0.48 & 2.29 & $\begin{array}{c}33.0 \\
8\end{array}$ & 89.8 & 0.31 & 1.1 \\
\hline 1 & Zhao & \multirow{4}{*}{35} & 0.59 & 1.29 & $\begin{array}{c}39.6 \\
2\end{array}$ & 80.18 & 0.23 & 1.13 \\
\hline 2 & $\begin{array}{c}\text { Hua } \\
\text { ng }\end{array}$ & & 0.86 & 1.92 & $\begin{array}{c}41.8 \\
5\end{array}$ & 154.44 & 0.45 & 1.2 \\
\hline 3 & QIu & & 0.74 & 1.71 & $\begin{array}{c}41.0 \\
9\end{array}$ & 141.78 & 0.42 & 1.17 \\
\hline 4 & Yan & & 0.43 & 0.97 & $\begin{array}{c}38.4 \\
5\end{array}$ & 99.84 & 0.3 & 1.1 \\
\hline 2 & $\begin{array}{c}\text { Hua } \\
\text { ng }\end{array}$ & \multirow{2}{*}{40} & 0.76 & 1.63 & $\begin{array}{c}46.6 \\
5 \\
\end{array}$ & 137.21 & 0.35 & 1.17 \\
\hline 3 & QIu & & 0.65 & 1.39 & $\begin{array}{c}45.6 \\
8\end{array}$ & 109.31 & 0.28 & 1.14 \\
\hline 2 & $\begin{array}{c}\text { Hua } \\
\text { ng }\end{array}$ & \multirow{2}{*}{45} & 0.68 & 1.39 & $\begin{array}{c}51.3 \\
8\end{array}$ & 104.7 & 0.24 & 1.14 \\
\hline 2 & $\begin{array}{c}\text { Hua } \\
\text { ng }\end{array}$ & & 1.65 & 6.92 & $\begin{array}{c}15.4 \\
3\end{array}$ & 93.83 & 0.95 & 1.54 \\
\hline
\end{tabular}



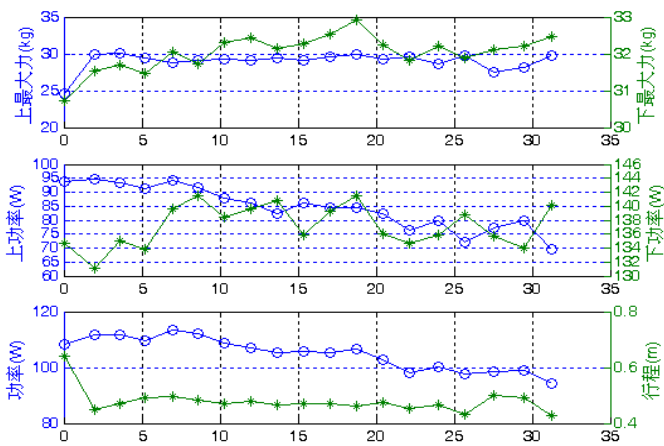

Fig 3-1 CuRves Showing the Pull-Back vs Max Release Force, THE PULL-BACK VS RELEASE POWER AND THE POWER VS STROKE RELATIONS OF ZHAO AT THE TEST
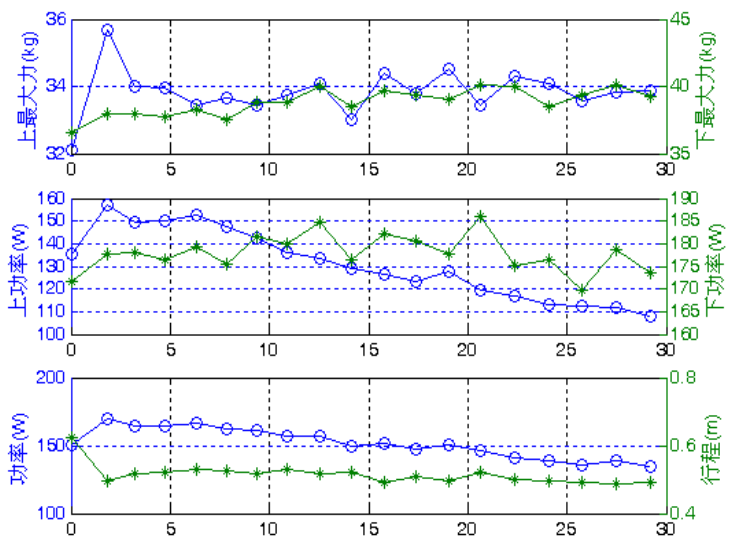

FIG 3-2 CURVES SHOWING THE PULL-BACK VS MAX RELEASE FORCE, THE PULL-BACK VS RELEASE POWER AND THE POWER VS STROKE RELATIONS OF HUANG AT THE TEST
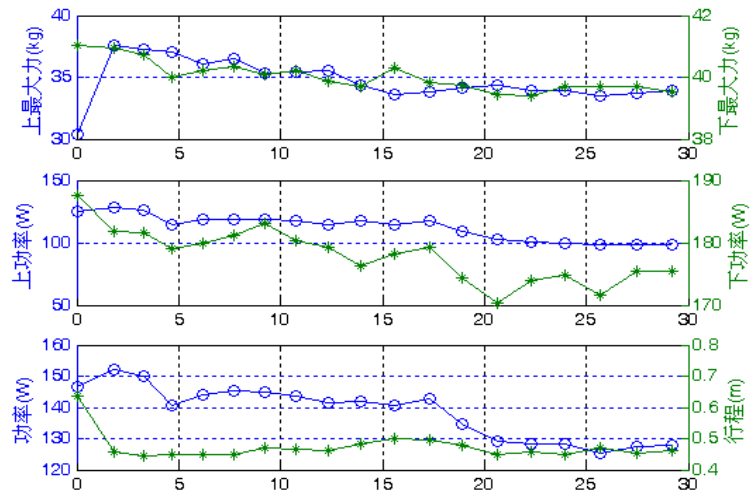

FIG 3-3 CURVES SHOWING THE PULL-BACK VS MAX RELEASE FORCE, THE PULL-BACK VS RELEASE POWER AND THE POWER VS STROKE RELATIONS OF QIU AT THE TEST
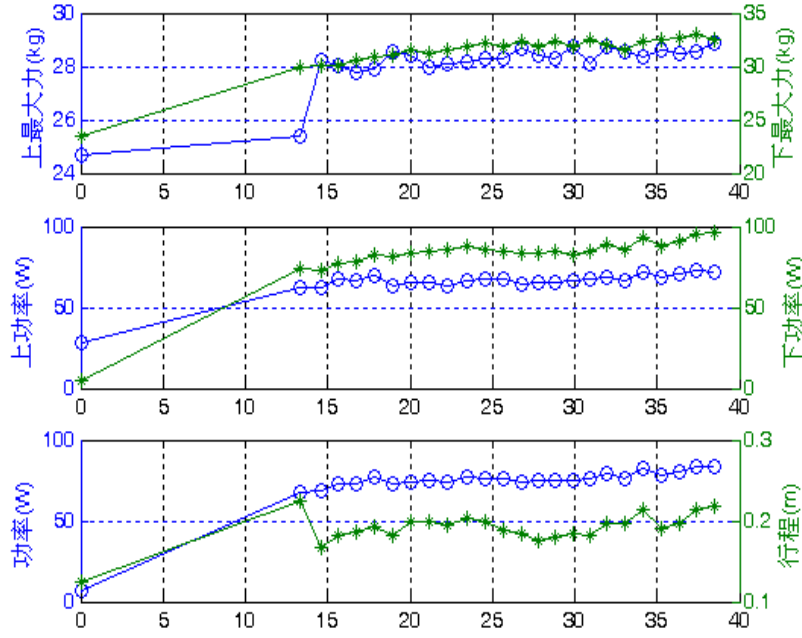

FIG 3-4 CURVES SHOWING THE PULL-BACK VS MAX RELEASE FORCE, THE PULL-BACK VS RELEASE POWER AND THE POWER VS STROKE RELATIONS OF YAN AT the test

\section{A. Speed analysis}

From Table 3-2, under the same weight of iron sheet, the maximum pull and peak pull-back power needed to pull back the iron sheet vary with the speed and acceleration. For $10 \mathrm{~kg}$ iron sheet, the maximum pull needed by the 4 athletes to pull back the sheet was as much as $93.83 \mathrm{~kg}$ compared to the minimum of $46.04 \mathrm{~kg}$, suggesting that under the same weight of iron sheet, the effect can vary significantly when different pull velocities and accelerations are applied in the exercise. This is an implication that in daily physical exercise, especially in cases when iron sheet or other weights are used, the velocity and acceleration of the pulling weights should be addressed in addition to the weight of the weights used.

\section{B. Power analysis}

As calculated, the maximum pull-back force was $45 \mathrm{~kg}$ for Zhao, $52 \mathrm{~kg}$ for Huang, 55kg for Qiu and 54kg for Yan. As the exercise weight increased, the maximum pull-back velocity, average pull-back velocity and pull/weight ratio gradually decreased for all the four athletes. However, a different thing happened to the average pull-back power. The athletes showed unexceptional variation of their average power under different weights with the level of their strength.

Further analysis revealed that when the exercise weight increased from $10 \mathrm{~kg}$ to $20 \mathrm{~kg}$, the average power for iron sheet pull of Zhao increased accordingly and went up to the maximum average power recorded of the test of $115.6 \mathrm{w}$; when the exercise weight increased to $25 \mathrm{~kg}$, however, her average pull-back power dropped substantially to $90.63 \mathrm{w}$; at the weight of $30 \mathrm{~kg}$, this rose slightly to $96.92 \mathrm{w}$, followed by continuous fall.

For Huang, the maximum power point occurred at the weight of $35 \mathrm{~kg}$ when his average pull-back power reached 
154.44w. After that, his average pull-back power, which had continued to increase with the weight, started to drop gradually.

The same happened to Qiu except that his maximum power point came at the weight of $30 \mathrm{~g}$, when his average pull-back power was 136.67. After that, his average pull-back power, which had continued to increase with the weight, started to drop gradually.

Yan was a special case. As the exercise weight continued to increase, so did her average pull-back power, and the maximum power turning point did not occur before the end of the test weight.

For all the exercise weights, among the three athletes included in the backstroke pull test, Huang had the maximum average pull-back power, followed by Qiu and Zhao.

In general, Huang presented better strength quality in the test. Qiu presented agreeable strength quality and satisfactory quality of movements in this phase of test as he was a young newcomer whose qualities were on the rise. Zhao demonstrated considerable fluctuation and similarity of force application in the exercise with the energy distribution she presented in competitions. In $200 \mathrm{~m}$ backstroke, for example, she was always significantly slower in the $3^{\text {rd }}$ of the $450 \mathrm{~m}$ segments before a steep acceleration was gained in the $4^{\text {th }}$, displaying outstanding thrust ability. Zhao's "hold back a card" phenomenon has once become the bottleneck for her overall physical ability. Yan's performance in the test disclosed insufficient exercise weight she used for her main style breast stroke - her exercise usually stopped before the true effect was achieved, and incomplete movements of exercise - her body kept moving up and down throughout the breast stroke, forming certain obstacle to the performance of her upper limbs strength.

\section{CONCLUSIONS AND RECOMMENDATIONS}

The exercise approach to the power for iron sheet pull of athletes from Hubei Provincial Swimming Team was tested with proprietary strength quality testing facility. Results indicated that the strength quality of a swimmer can be assed by velocity variation, and the strength level of an athlete can be measured with the proportion of the amplitude of speed variation to the average speed. Application confirmed that this testing method helps coaches design quantitative exercise and improve the scientific level of exercise. Insufficient weight of iron sheet for strength exercise will not be stimulating enough to achieve the objective of exercising athletes. The weight of iron sheet can be increased moderately to increase the stimulation of loads to athletes, thereby achieving the objective of improving their strength quality. During exercise, athletes can be asked to exercise under time restriction so that they will perform each movement at a higher frequency and the highest speed and complete each set of exercise within the shortest time possible, as a means to improve their exercise intensity and consequently their strength quality.

\section{REFERENCES}

[1] LanShi Feng, Meiyun Feng, Weiquan Feng. Function Evaluation Method of Elite Athelets[M]. Beijing: Peoples Sports Publishing House, 2003.

[2] Yongxia Xiao, Jianshen Gao. Simple Analysis of the Special Strength Trainning of Rowing Atheles[J]. Journal of Anhui Sports Science, 2002, (2): 59—61.

[3] Huajie Zhang. The strength quality of rowing athletes and its training method[J]. Journal of wuhan institute of physical education, 1998, (1): 38-41.

[4] Xu Chen, Weitao Zheng: Developing and application of Testing and Assessment System of Weight exercise by Gravity [J]. Journal of wuhan institute of physical education, 2001,4,(2): 111-113.

[5] Huajie Zhang, Weitao Zheng, Yong Ma. Analysis of maximum power quality test of Wuhan Institute of Female Rowers[J]. Journal of wuhan institute of physical education, 2004,(9):69—73. 